\title{
Benefits and risks of antimicrobial use in food-producing animals
}

\author{
Haihong Hao', Guyue Cheng ${ }^{1}$, Zahid Iqbal' ${ }^{1}$, Xiaohui Ai ${ }^{2}$, Hafiz I. Hussain ${ }^{1}$, Lingli Huang ${ }^{1}$, \\ Menghong Dai ${ }^{1}$, Yulian Wang ${ }^{3}$, Zhenli Liu ${ }^{3}$ and Zonghui Yuan ${ }^{1,3}$ * \\ ${ }^{1}$ MOA Laboratory for Risk Assessment of Quality and Safety of Livestock and Poultry Products, Huazhong Agricultural University, Wuhan, China
${ }^{2}$ Yongtgz River Fisheries Research Institute, Chinese Academy of Fishery Sciences, Wuhan, China
${ }^{3}$ National Reference Laboratory of Veterinary Drug Residues and MOA Key Laboratory for the Detection of Veterinary Drug Residues in Foods, Huazhong
Agricultural University, Wuhan, China
}

Edited by:

Robert Paul Hunter, Lilly, USA

Reviewed by:

Jer-Horng Wu, National Cheng Kung

University, Taiwan

Robert Paul Hunter, Lilly, USA

*Correspondence:

Zonghui Yuan, MOA Laboratory for Risk Assessment of Quality and

Safety of Livestock and Poultry

Products, College of Veterinary

Medicine, Huazhong Agricultural

University, Wuhan 430070, Hubei,

China

e-mail: yuan5802@mail.hzau.edu.cn
Benefits and risks of antimicrobial drugs, used in food-producing animals, continue to be complex and controversial issues. This review comprehensively presents the benefits of antimicrobials drugs regarding control of animal diseases, protection of public health, enhancement of animal production, improvement of environment, and effects of the drugs on biogas production and public health associated with antimicrobial resistance. The positive and negative impacts, due to ban issue of antimicrobial agents used in foodproducing animals, are also included in the discussion. As a double-edged sword, use of these drugs in food-animals persists as a great challenge.

Keywords: antimicrobial drug, benefit, risk, animal food production, public health

\section{INTRODUCTION}

Over the decades, world population tremendously increased to 7 billion (Food and Agriculture Organization [FAO], 2012) and 870 million $(12.5 \%)$ of them were estimated to be undernourished during 2010-2012 (Food and Agriculture Organization [FAO], 2012; Krehbiel, 2013). Demand for animal source food tends to be soaring day by day, especially in developing countries (Food and Agriculture Organization [FAO], 2009; Krehbiel, 2013). It is acknowledged that the antimicrobial use is one of the most successful chemotherapies. Various antimicrobials have made significant contribution for the prevention, control, and treatment of infectious diseases in animals since 1940s (Forman and Burch, 1947). Low and sub-therapeutic dose of antimicrobials plays very important role for the improvement of feed efficiency, promotion of animal growth, and prevention and control of the diseases (Dibner and Richards, 2005; Niewold, 2007). International market value of veterinary drugs (including antimicrobials) tremendously increased from $\$ 8.65$ billion in 1992 to $\$ 20.1$ billion in 2010 and in 2018 , it is expected to increase to $\$ 42.9$ billion (GIA, 2012; Reports, 2012).

It is undeniable that rational use of antimicrobials plays a vital role in the production of food animals and protecting public health, while irrational and irresponsible use may cause antimicrobial resistance. On the basis of "Swan Reports" in 1969, Great British took first action for the restriction of antibiotics, being used in animals or capable of cross-resisting with antibiotics used in human medicine. In 1973, the European Community (EC) commenced the withdrawal of some important antibiotic use as growth promoters in animal feed. After that, Sweden banned the use of all growth-promoting antibiotics in 1986. Avoparcin, bacitracin, spiramycin, tylosin, and virginiamycin were withdrawn as growth promoters in the European Union (EU) from 1995 to 1999, on the basis of precautionary principle. In 2006, all the uses of low-dose antibiotics (5 40 ppm) in food animals, including flavomycin, avilamycin, salinomycin, monensin, and other animal-specific antibiotics, were banned in the $\mathrm{EU}$ with the intention to avoid their negative impact of resistant development (EPC, 2005; Marshall and Levy, 2011).

The benefits and risks of antimicrobials continue to be complex and controversial issues. The risks of antimicrobial drugs to public health associated with antimicrobial resistance raised great concern recently, while the benefits of antimicrobial drugs, such as prevention and treatment of animal diseases, protection of public health, enhancement of animal production, and improvement of environment, were disregarded most of the time. Many benefit-related claims have not yet been fully demonstrated in large-scale trials, and other trials revealed that the overall impact of the short-term benefits was poorly described. This article presents the benefits and risks of antimicrobials drugs used in food animals and discusses the positive and negative effects of the ban on antimicrobial growth promoters.

\section{BENEFITS OF ANTIMICROBIAL DRUGS PREVENTION AND TREATMENT OF ANIMAL DISEASES}

With intensive animal production, bacterial and parasitic diseases became more and more frequent. According to an estimate, 80 types of bacteria, such as Escherichia coli, Salmonella, and Clostridium welchii, posed a serious threat to poultry industry. Mastitis, caused by Staphylococcus aureus in dairy animals, led to 
a loss of $\$ 2$ billion/year in the United States of America (USA) and an average cost of $€ 485 /$ dairy cow in the EU during 2012 (Heikkila et al., 2012). Due to infection caused by Streptococcus pneumonia, morbidity and mortality rates in calves increased to 40 and 20\%, respectively (Akkermans and Vecht, 1994; Vogel et al., 2001). More than $50 \%$ of aquatic animals were infected by bacteria each year (Scarfe et al., 2011). Vibrio vulnificus became a potential health hazard for aquatic animals and human beings (Yano et al., 2004).

Approximately, 2169 parasites including 203 protozoa, 373 trematodes, 150 tapeworms, 404 nematodes, and 1030 arthropods have been found in livestock and poultry in China. About 4-20 billion dollars/year ( $8.3 \%$ annual output of animal husbandry) were lost due to parasitic diseases caused by coccidia, nematodes, ticks, and others in USA (Krausse and Schubert, 2010). Acute outbreaks of chicken coccidiosis paid a loss of 42 million pounds annually in the United Kingdom (Franklyn et al., 2010). In China, poultry industry had to face billions of dollars annual loss due to almost $100 \%$ chicken morbidity by coccidiosis (Zhang et al., 2013). Sheep helminthiasis led to a loss of 2.22 million dollars annually in Australia (Hosking et al., 2009; Larsen et al., 2009).

Over one hundred of antimicrobials, including $\beta$-lactams, aminoglycosides, tetracyclines, amphenicols, macrolides, sulfonamides, fluoroquinolones, lincosamides, polypeptides, and polyene, have been used in food-producing animals around the world. These antimicrobials have played an essential role in the prevention, treatment, and control of food animal diseases caused by pathogens, such as pathogenic E. coli, S. aureus, S. pneumonia, Actinobacillus pleuropneumoniae, mycoplasma, Vibrio, and others (Hoflack et al., 2001; Krausse and Schubert, 2010). It was reported that in USA, $52.1 \%$ of total antimicrobials were used for the treatment of infectious diseases in animals, where $90 \%$ of starter pigs, $75 \%$ of grower pigs, $50 \%$ of finisher pigs, and $25 \sim 70 \%$ of cattle received the drugs through feed (Van Lunen, 2003; USFDA, 2009; GRACE, 2013). With a dose of $40 \mathrm{mg} / \mathrm{kg}$, avilamycin in feed could remarkably decrease the incidence of diarrhea in postweaning pigs (Partanen et al., 2007). When salinomycin was used in sows and pigs simultaneously, incidence of diarrhea in piglets was significantly reduced and the survival rate was increased by 13.95\% (Nagaraja and Taylor, 1987). Sulfonamide and folic acid supplementation in diet increased live birth rate of piglets by $1 \%$ (Lindemann and Kornegay, 1989). Hence, it is concluded that the use of antimicrobials is a primary strategy for prevention and treatment of bacterial infections in food-producing animals.

Many antimicrobials have strong activity against parasites in animals. Use of sulfonamides in animals opened a new era of anti-parasitic drugs and made lots of parasitic diseases under control. Up till now, anti-parasitic drugs have shared about onethird sale of the global veterinary drug markets. Macrolides and benzimidazoles effectively controlled nematodes. Doramectin and ivermectin helped to prevent infection of Argulus siamensis in carp and Labeo rohita (Hemaprasanth et al., 2012). In rabbit, subcutaneous injection of ivermectin, at dose of $400 \mathrm{mg}$ per $\mathrm{kg}$, not only helped to clinical cure ear mite infection but also prevented loss of fur and thus, played a vital role for the improvement of fur production (McKellar et al., 1992).
Conclusively, due to unique advantages, such as exact targeting of pathogens, well-known mechanisms of activity and desired stability, antimicrobials justified their usage in livestock and poultry, and played important part for prevention and treatment of bacterial and parasite diseases.

\section{PROTECTION OF HUMANS AGAINST ZOONOSIS}

Among animal infectious and parasitic diseases, more than 200 can affect human life. Campylobacter spp., Salmonella spp., E. coli O157, Vibrio parahaemolyticus, and Aeromonas hydrophila from animals pose great health threat to both humans and animals (Altwegg and Geiss, 1989; Mellata, 2013). The United States Centers for Disease Control and Prevention (US-CDC) estimated that there were about 76 million annual cases of foodborne illness in USA, including 325,000 hospitalizations and 5000 deaths (Mead et al., 1999a). Annual cases of Campylobacter spp., Salmonella spp., E. coli O157, and V. parahaemolyticus were $1,963,000,1,332,000,62,500$, and 5000, respectively (Mead et al., 1999a,b).

To some extent, antimicrobial agents guaranteed human food security and public health by controlling animal diseases and preventing transmission of zoonotic pathogens from animals to humans. When added to animal feed or drinking water, these drugs could significantly decrease the bacterial contamination in animal products. For examples, virginiamycin decreased the contamination of Clostridium perfringens, Campylobacter spp., and other food-borne pathogens in animal carcasses (Tice, 2001; Russell, 2003; Hurd etal., 2005). Salinomycin reduced infection of type C Clostridium in sows and weaning piglets by $43 \%$ (Nagaraja and Taylor, 1987). Neomycin in animal feed significantly reduced the number of E. coli O157: H7 in animal feces, and gentamycin reduced bacterial count in poultry eggs and meat (Elder et al., 2002; Doyle and Erickson, 2006). When cattle was fed with neomycin sulfate for $48 \mathrm{~h}$ and held for 24-h drug withdrawal period before slaughtering, it shed considerably less E. coli O157:H7 cells than those pen mates who did not receive the treatment (Elder et al., 2002). A farm-level study in 2008 by Ohio State University demonstrated that only $39 \%$ of hogs, raised on conventional antimicrobial operations, were infected with Salmonella, while those were $54 \%$ in case of antimicrobial-free operations (Nunes, 2008; AMI, 2010). Florfenicol $(10 \mathrm{mg} / \mathrm{kg})$ presented $100 \%$ efficiency for the treatment of A. hydrophila of Piaractus mesopotamicus (Carraschi et al., 2012). Oxytetracycline hydrochloride or norfloxacin in bait feed reduced the number of $A$. hydrophila in water by $46.86 \sim 66.24 \%$, indicating that the risk of the bacterial infection to humans be decreased.

\section{ENHANCEMENT OF ANIMAL PRODUCTION}

In 1943, a few farmers in USA found that pigs fed with penicillinfermented mixture grew faster (Wahlstrom et al., 1950; Hewes, 1955; Taylor and Gordon, 1955). In 1946, Moore found that low dose of streptomycin stimulated chick's growth (Moore and Evenson, 1946; Dibner and Richards, 2005). Subsequently, chlortetracycline, doxycycline, and sulfonamides helped growth promotion in calves, pigs, and chicken. Cunha from University of Florida and Stokstad from University of Washington 
reported that penicillin in fermentation mixture functioned as a growth promoter for food-animals (Cunha et al., 1951). Legal use of the antimicrobials in feed has a history of over 60 years. Food and Drug Administration in USA (US FDA) approved these drugs as growth promoters for animals in 1951. Till 1978, $47.9 \%$ of the antimicrobials were used to be added in animal feed in USA. About $60 \%$ of poultry, $93 \%$ of chicken, $97 \%$ of growing pigs, and $80 \%$ of fattening pigs received antimicrobials through diet during the early 1990s. More than $40 \%$ of the drugs were added in animal feed at subtherapeutic level for improving animal production in USA during 1990s (Van Lunen, 2003). With a substantial contribution to the development of food-animal production at global level, veterinary antimicrobials tend to be necessities to cope with increasing food demand for humans.

Role of antimicrobials for the improvement of feed conversion ratio (FCR), animal growth, and reproductive performance has been well proven as given in Table 1, and discussed under following points (Cromwell, 2002). (1) Orally administered antimicrobials in pigs increased diet digestibility and improved feed utilization efficiency by $1.7 \sim 5.1 \%$ and $6.9 \sim 7 \%$, respectively (Cromwell, 1999; Hardy, 1999; JETACAR, 1999; Van Lunen, 2003). (2) Addition of the drugs (e.g., chlortetracycline, sulfonamide, folic acid, carbadox, tilmicosin, tylosin, or sulfamethazine) in feed could remarkably improve the conception rate, farrowing rate, milk secretion, productive efficiency of sow, and live birth rate of piglet (Soma and Speer, 1975; Lindemann and Kornegay, 1989; Alexopoulos et al., 1998; Kantas etal., 1998; Weber etal., 2001; Partanen et al., 2007). (3) Feeding antimicrobials to pigs increased their weight gain by 1.9 16.4\% (Nagaraja and Taylor, 1987; Cromwell, 1999; JETACAR, 1999; Van Lunen, 2003; IFAH-EuroP, 2005). (4) Administration of antibiotics (bacitracin zinc, colistin sulfate, flavomycin, and florfenicol) in fish diet significantly improved the feed conversion and promoted their growth (He et al., 2011; Zhou etal., 2011). (5) Antimicrobial (tiamulin, nosiheptide,

Table 1 | Part of evidences for the role of antimicrobials on feed utilization, growth promotion, reproductive performance, and carcass quality.

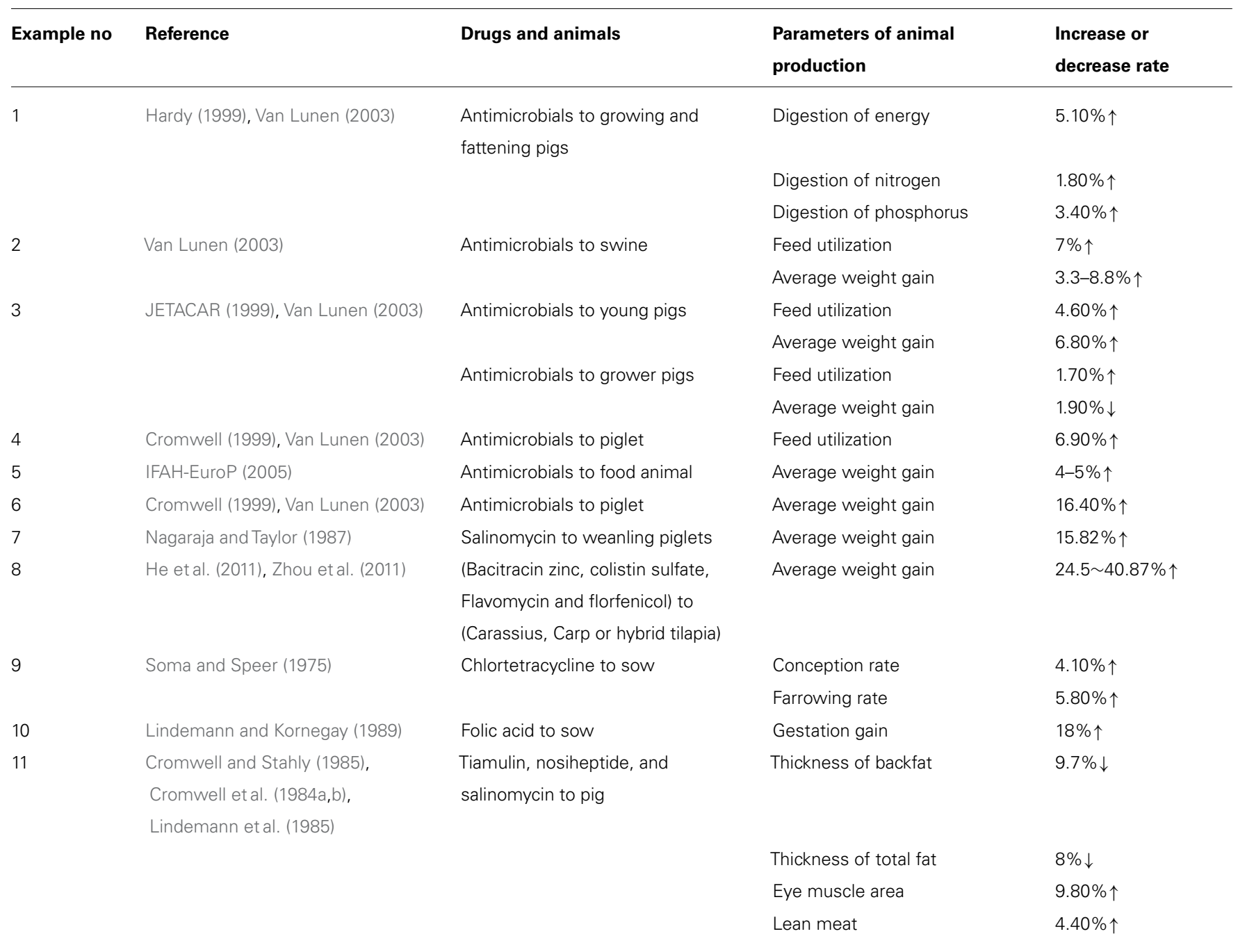

$\uparrow$ Denotes increase, while $\downarrow$ denotes decrease. 
salinomycin, and tylosin) supplementation could also improve the carcass quality by decreasing the fat thickness and increasing the lean meat of food-producing animals (Cromwell et al., 1984a,b; Cromwell and Stahly, 1985; Lindemann et al., 1985; Van Lunen, 2003).

A lot of studies were carried out to find the mechanism involved in beneficial aspects of antimicrobials in animals. Jukes, Franti, and other scientists proved that the drugs attenuated intestinal wall and improved the digestibility of nutrients (Manson, 1968; Falkow, 1970; Jukes, 1970; Franti et al., 1971, 1972; Dibner and Richards, 2005). Midtvedt (1986) and Norin (1997) confirmed that oral doses of antimicrobials improved the structure of intestinal flora (Midtvedt, 1986; Norin, 1997). Salinomycin and avilamycin in feed improved the bioavailability of $\alpha$-tocopheryl acetate in broilers by altering lipid absorption (Knarreborg et al., 2004). According to a previous review by Allen et al. (2013), antimicrobials have multifunctional role in animals, elaborated under following points: (1) these could reduce the colonization of intestinal bacteria and inhibit the growth of pathogenic microorganisms; (2) by decreasing the thickness of mucous membrane, led to more absorption of nutrients and reduced fermentation; (3) they directly neutralized the host immune response. In short, antimicrobials could affect the host intestinal flora, intestinal physiology, and immune system, and consequently, prevent disease, improve feed conversion, and enhance the growth of animals (Niewold, 2007). Till now, there are no appropriate alternatives which can replace antimicrobial growth promoters, in case those remain banned. Although numerous feed additives, mainly pre- and pro-biotic products, are commercially available now and seem to have potential to replace these growth promoters, but their true efficacy and mechanism of action in domestic animals remain unclear because of some inconsistent experimental results (Gaggia et al., 2010; Allen et al., 2013). Additionally, lack of safety evaluation and poor stability also limited the practical use of pre- and pro-biotic as feed additives.

\section{IMPROVEMENT OF ENVIRONMENT}

According to a report of Center for Food Safety (CFS, 2013) and Food and Agriculture Organization (FAO, 2006), housing stress, due to over-crowding of animals, creates sweeping and devastating impacts on the natural and human environment leading to global warming, land degradation, air and water pollution, and loss of biodiversity. Livestock waste is one of the major sources of greenhouse gases, as the abnormal fermentation of gastrointestinal tract contents can produce lots of methane, ammonia, carbon dioxide, as well as stench gases (e.g., nitrate, ethylene acid, methyl mercaptan, hydrogen sulfide, methylamine, and trimethylamine). Fecal waste of animals generally contains $24 \%$ protein and $6.1 \sim 17.96 \%$ amino acids. Nitrogen and phosphorus in the waste lead to environmental pollution, water eutrophication and ecological imbalance.

Some antimicrobials in feed could inhibit the abnormal fermentation and consequently, reduce the emission of greenhouse gases (mainly $\mathrm{CH}_{4}$ ). For example, ionophores (monensin, lasalocid, and salinomycin), amoxicillin, ovoparcin, nigericin, or laidlomycin inhibited rumen microbial fermentation at different levels and thus, reduced the proportion of volatile fatty acids
(VFA) and methane (Van Nevel and Demeyer, 1995; Fellner et al., 1997; Domescik and Martin, 1999). Since the mid-1970s, ionophorous antibiotics have been widely used as feed additives in ruminants due to their favorable effects on rumen fermentation and methane reduction (Kobayashi, 2010). Due to the efficacy and affordable price, ionophores have widely been used to reduce methane emission from livestock (Hook et al., 2010; Kobayashi, 2010). When ionophores (monensin and lasalocid) were mixed with rumen microorganisms in vitro, these inhibited methane by 50 and $44 \%$, respectively and decreased $\mathrm{NH}_{3}$ by more than 50\% (Russell and Jeraci, 1984). In rumen models, ionophores (monensin, lasalocid, and salinomycin) inhibited 10 20\% lipolysis and biological hydrogenation (Van Nevel and Demeyer, 1977, 1995). The effects of the antibiotics on the abatement of methane production may be attributed to a selective antimicrobial action on rumen microbes (protozoa, ruminococci, streptococci, and lactobacilli). Addition of monensin and lasalocid in cow forage killed 82.5 and $76.8 \%$, respectively, of the intestinal ciliated protozoa in rumen and hence, reduced the production of methane and VFAs (acetic acid and propionic acid) by ciliates (Guan et al., 2006). Generally, the gas production was reduced from 4 to $31 \%$ by monensin (Schelling, 1984; Rumpler et al., 1986; Kobayashi, 2010). A recent report has indicated that long-term administration of monensin in dairy cattle steadily reduced methane by $7 \%$ and this reduction persisted for 6 months with no adverse effect on milk yield (Odongo et al., 2007). However, previous studies also found that both, the methane level and protozoal number, returned to baseline after long-term administration of high concentration of the antibiotic (Guan et al., 2006; Odongo et al., 2007; Hook et al., 2010). The efficiency of monensin supplementation, for reducing methane output in ruminants, appeared to be different in the degree of abatement depending on the diet and animal used (Guan et al., 2006; Odongo et al., 2007; Hook et al., 2010). Effect of the drug on the methane levels in rumen was closely related to the ciliated, protozoal population. Microbial consortia, like protozoal population, in the ruminant gut may adapt to the antibiotics leading to the recovery of methane production yield, in case of a long-term usage. Therefore, the ciliates in the rumen may impact the outcome of antimicrobial supplementation, with adaptation being a possibility (Guan et al., 2006; Hook et al., 2010).

Through manure application, antibiotics got released into soil and could be absorbed by plants in arable land. Certain species of plants have the ability to bio-accumulate sulfamethoxine in their roots and stems, and this bioaccumulation was often higher in roots than in stems (Sarmah et al., 2006). Low concentrations of chlortetracycline and oxytetracycline in the soil media could markedly affect plant growth and development (Sarmah et al., 2006). However, there was a large variation in sensitivity among plant species to the soil used as the growth media (Sarmah et al., 2006).

When residues seeped into water, certain antimicrobials also played significant role in the prevention of water eutrophication for aquatic animals. For example, chlortetracycline, lomefloxacin hydrochloride, and sulfamethoxazole strengthened the absorption of nitrogen and phosphorus in water by aquatic plants, and chlortetracycline effectively removed $25 \%$ of water nitrate and 
nitrogen (Dodds et al., 1991; Jones, 2010). On the other hand, the presence of antibiotic residues in environment may cause some adverse impacts, like acute and chronic toxicity, during early life stages of different aquatic organisms (Halling-Sorensen et al., 2003; Sarmah et al., 2006).

\section{NEGATIVE IMPACT OF ANTIMICROBIAL BAN}

Ban on addition of sub-therapeutic antimicrobials in feed appeared to result in a certain extent of recovery of some bacteria and some unintended impacts on animal health and welfare (Drouin, 1999; Rose et al., 1999; Lovland and Kaldhusdal, 2001; Jensen et al., 2003). Emergence of E. coli and Lawsonia intracellularis infection in post-weaning pigs was significantly increased and consequently, the morbidity and mortality due to diarrhea were considerably increased (Casewell et al., 2003; Dibner and Richards, 2005). In Denmark, the mortality rate in weaning piglets increased from $2.7 \%$ (before the ban) to $3.5 \%$ (after the ban) and the morbidity rate of enteric infections in postweaning pigs increased by 600\% (Casewell et al., 2003; Dibner and Richards, 2005). In Sweden, chronic infections due to E. coli and L. intracellularis became more common and the mortality in weaning pigs increased by $1.5 \%$ (Wierup, 2001; Casewell et al., 2003).

To control animal diseases and to keep animals healthy, more therapeutic antimicrobials had to be used after the ban. It was reported that the usage amount of therapeutic antimicrobials in Denmark increased by 33.6\%, from 48 tons/year in 2001 to 125.5 tons/year in 2010 (DANMAP, 2010). The increased amount of therapeutic antimicrobials was equal to or even more than the total quantity of antimicrobials being used before the ban (Phillips, 1999; Casewell et al., 2003; Phillips et al., 2004a,b; Turnidge, 2004; DANMAP, 2010). As shown in Figure 1, therapeutic use of tetracycline, penicillins, and macrolides markedly increased from 28.5, 16.4, and 13.4 tons in 2001 to $35.55,27.1$, and 16.8 tons in 2010, respectively (Phillips, 2007; DANMAP, 2010).

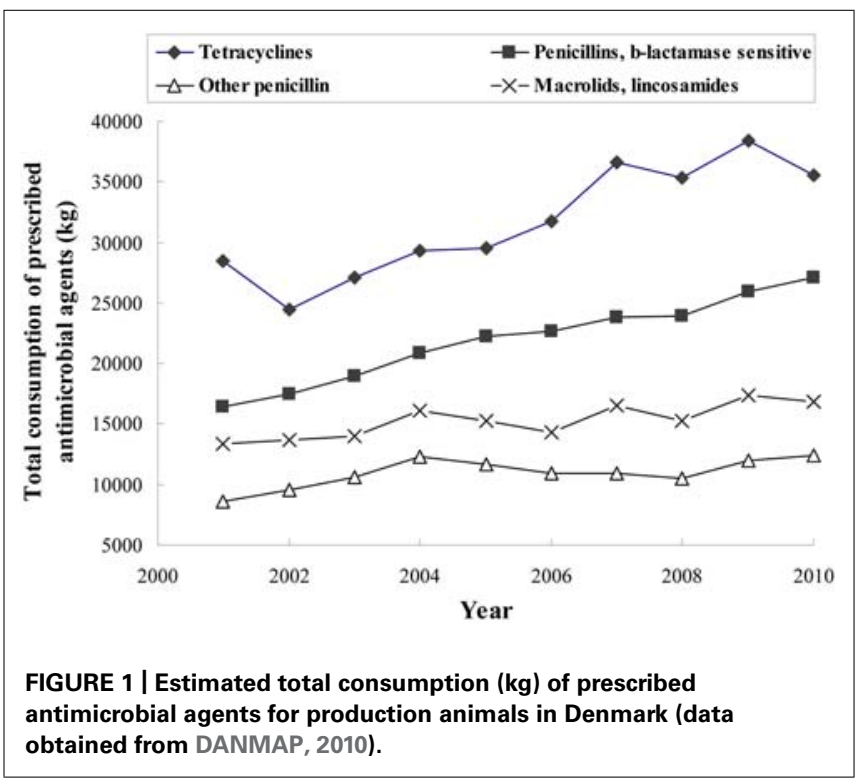

Withdrawal of low-dose antimicrobial use as feed additives may increase the level of pathogens such as Salmonella spp., Campylobacter spp., Clostridium and E. coli $\mathrm{O} 157$ in animal gut, boost the contamination of food and environment, and hence, enhance the opportunities for humans to be infected by these pathogens. Population of Campylobacter in broilers fed without antimicrobials was threefold higher than that in the broilers fed with any antimicrobials (Heuer et al., 2001). Incidence of foodborne Campylobacter in EU has been increased after the ban issue. Recovery of Clostridium from animal meat was also significantly increased in EU after its ban policy (Jones, 2000; Poduval et al., 2000). As a consequence, clostridial infections resulted in an outbreak affecting large human population in Demark and pointed out the high level of threat to public health (DANMAP, 2010). It is known that clostridial necrotic enteritis in animals is suppressed by some of the banned antimicrobials (e.g., virginiamycin). In the absence of these antibiotics, the bacterial population may increase in animal guts and colonization may lead to poor weight uniformity and fragile intestines in pigs and chicks. During food processing, infected animal carcasses could be the sources of contamination for food-borne pathogens and thereby, jeopardize food hygiene (Tice, 2001; Russell, 2003). Bacterial contamination of meat may, therefore, increase the risk of human infections. Contrary to EU, incidence of food-borne diseases in USA was declined by $23 \%$ in 1996 and among those, the infections due to Campylobacter and Salmonella were decreased by 30 and $17 \%$, respectively. It was believed that ban of virginiamycin in USA might annually contribute to the death of 40,000 people, infected by Campylobacter (Cox, 2005).

The ban may lead to increased food-borne infections and elevated usage of therapeutic antimicrobials in both animals and humans. It is noteworthy that therapeutic use of antimicrobial agents in animals has a close relationship with the drugs used in humans with respect to the types of drugs used (Cook, 1999). The increased therapeutic use in animals may contribute to a worse, drug-resistance scenario both in animals and humans. It was noted that clinical isolates of vancomycin- or teicoplaninresistant Enterococci from humans were very uncommon and the cases of quinupristin/dalfopristin-resistant Enterococcus faecium were very rare before the ban. Similarly, resistant E. faecium burden markedly increased and became a big challenge after the ban (Phillips, 2007).

After the European ban on growth-promoting antibiotics, it was found that FCR (total $\mathrm{kg}$ of feed used per grow out/total $\mathrm{kg}$ of live weight per grow out) in broiler was decreased by $0.016 \mathrm{~kg} / \mathrm{kg}$ from November 1995 to May 1999 (1.78-1.796) in Denmark. Feed efficiency raised to a higher value of 1.83 immediately after the restrictions and more than 1.84 in late 1999 (Emborg et al., 2002; Dibner and Richards, 2005). Average daily gain of weaning piglets in Denmark was decreased from $422 \mathrm{~g}$ in 1995 to $415 \mathrm{~g}$ in 2001 (Casewell et al., 2003; Dibner and Richards, 2005). Production of broilers, cattle, and dairy cows was significantly decreased in 2006, as shown in Figure 2. In Sweden, weight gain of post-weaning piglets was reduced and feed costs were significantly increased after the abolishment of growth-promoting antimicrobial agents (Wierup, 2001; Casewell 


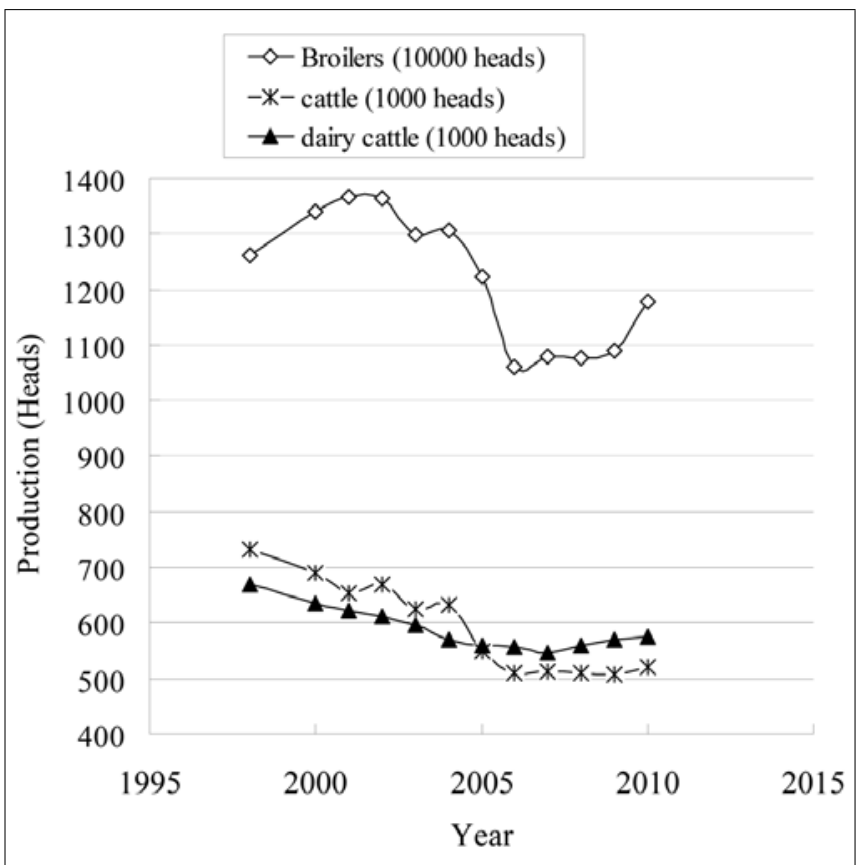

FIGURE 2 | Production of food animals in Denmark from 1998 to 2010 (data obtained from DANMAP, 2010).

etal., 2003). Even after 10 years, aquaculture production in Sweden was unable to return to the past level (Casewell et al., 2003).

If the use of antimicrobials is banned in USA, FCR may decline by $5 \%$ and more than $1100 \mathrm{~km}^{2}$ area is required to plant corn and soybeans to meet the demand of feedstuff production. Consequently, required facilities for livestock and poultry production will be correspondingly increased by 100 million $\mathrm{m}^{2}$, and farming area will also be increased by 500 million $\mathrm{m}^{2}$ to obtain the current level of animal production (Casewell et al., 2003). It was estimated that withdrawal of antimicrobial growth promoters might lead to a loss of $5 \sim 10$ or even 40 dollars/pig in USA (Matthews, 2001). It does not seem to be a high cost for the developed countries but what will be the consequences if these antimicrobials are banned worldwide? It was also investigated that $25 \%$ of the current poultry industry and $\$ 3$ billions would be additionally required to attain the current annual animal production (Rodehutscord et al., 2002; IFAH-EuroP, 2005). In conclusion, keeping in view the ever-increasing world population and its demands, more food animals should be raised to meet the food supply demand in the case of growth-promoting antibiotics remain prohibited and this increased number of animals will again lead to the increase in greenhouse gas emission and deeper environmental pollution.

\section{RISKS OF ANTIMICROBIALS INHIBITION OF BIOGAS PRODUCTION}

Following the wide use of antimicrobial drugs in intensive animal production for growth promotion and prevention or treatment of disease, a large proportion of ingested drugs are excreted in manure and end up with livestock wastewater. Excreted antibiotics in the environment may partially inhibit methanogenesis in anaerobic waste-storage facilities, commonly used at Concentrated Animal Feeding Operation (CAFOs), and thus, decrease the rate at which bacteria metabolize animal waste products (Loftin et al., 2005; Sarmah et al., 2006).

During the anaerobic digestion of livestock waste, certain antimicrobials, including amoxicillin, aureomycin, oxytetracycline, thiamphenicol, florfenicol, sulfadimethoxine, and tylosin, had inhibitory effects on methane production (Lallai et al., 2002; Sun etal., 2009; Shi etal., 2011; Amin etal., 2012). However, no inhibitory effect but a stimulus for methane production was observed during anaerobic digestion of piggery wastewater in the presence of $10 \mathrm{mg} / \mathrm{L}$ florfenicol, amoxicillin, aureomycin, and sulfadimethoxine, while only the combination of high concentration of certain antimicrobials $(130 \mathrm{mg} / \mathrm{L}$ florfenicol, $210 \mathrm{mg} / \mathrm{L}$ amoxicillin, $10 \mathrm{mg} / \mathrm{L}$ doxycycline, and $210 \mathrm{mg} / \mathrm{L}$ sulfadimethoxine) could decrease the methane production rate (Sun et al., 2009). Biogas volume, produced from per unit weight of biomass, was decreased with increasing concentrations of antibiotics, such as oxytetracycline, amoxicillin, and tylosin, and the inhibitory concentrations of oxytetracycline, amoxicillin, and tylosin were 8000,9000 , and $9000 \mathrm{mg} / \mathrm{L}$, respectively (Amin et al., 2012). Only high concentration of thiamphenicol $(160 \mathrm{mg} / \mathrm{L})$, amoxicillin $(120 \mathrm{mg} / \mathrm{L})$, tetracycline $(50 \mathrm{mg} / \mathrm{L})$, and sulfamethoxydiazine $(50 \mathrm{mg} / \mathrm{L}) \mathrm{had}$ inhibitory effect on biogas production in the anaerobic digestion of pig waste slurry (Lallai et al., 2002; Shi et al., 2011). Actually, it is too difficult to attain those high concentrations of antibiotics in the excreta.

\section{ANTIMICROBIAL RESISTANCE CONCERNS}

Misuse and overuse of antimicrobial may culminate in the development of drug-resistant pathogens resulting in poor response to treatment. Long-term and low-level exposure to antimicrobials may have greater selective potential than short-term and full-dose therapeutic use. A study observed that the percentage of tetracycline resistance genes in the fecal flora of conventionally raised feedlot steers was significantly higher than that in fecal samples from antimicrobial-free cattle (Harvey et al., 2009). Additionally, use of single antimicrobial may induce cross-resistance to antimicrobials used for animal and human medical therapy. For example, chlortetracycline use in growth rations was associated with ampicillin and tetracycline resistance in generic fecal $E$. coli, isolated from swine farms (Varga et al., 2009). Addition of chlortetracycline and sulfamethazine in cattle feed may be associated with higher prevalence (three to four fold greater than the control) of ampicillin- and tetracycline-resistant E. coli, isolated from the feces of treated animals (Alexander et al., 2010). Therefore, how to use antimicrobials, for effective treatment of bacterial and parasitic infections in food-producing animals, became the most important question for their use by avoiding the resistance development.

Regarding public health risk, more concern has been raised for the use of antibiotics in animals that may represent a potential threat to human health because the resistant pathogens in animals may transmit to humans and cause treatment failure of human medicines. A longitudinal study of the relationship 
between antimicrobial-resistant $E$. coli from human wastewater and swine fecal samples reported that the use of injectable (e.g., ceftiofur sodium) or oral (e.g., chlortetracycline) antibiotics may contribute to the high levels of E. coli resistance in swine and human isolates. Thus, slaughter plant workers may be at higher risk of carrying multidrug-resistant E. coli as compared to workers dealing with other animals (Alali et al., 2008). A study analyzed the correlation between E. coli isolates from human blood stream and food-producing animals (poultry, pigs, and cattle) for the prevalence of antimicrobial resistance in 11 countries during 2005-2008. Results revealed that there were strong and significant correlations between the strains from animals (especially poultry and pigs) and humans for resistance to multiple drugs (especially ampicillin, aminoglycoside, and fluoroquinolone; Vieira et al., 2011). However, there is not enough and direct evidence to support the hypothesis that a large proportion of resistant isolates in humans be derived from animal source foods. Some recent studies suggested that some resistant isolates from humans were more easily transmitted from companion animals (having close contact) or birds (by bird droppings especially during their migration; Haenni et al., 2012; Loncaric et al., 2013). The resistant bacteria may also be released into the environment by humans and then transferred into new hosts in the environment (Hower et al., 2013; Verkade and Kluytmans, 2013). Based on the results of some current studies, Dr. Hurt pointed out that public health risk due to infected animals need more attention than antibiotic resistance concern (Hurd et al., 2008, 2012). Therefore, further efforts are required for the risk assessment of antimicrobial use in food animals to check their potential impact on public health.

\section{POSITIVE EFFECTS OF ANTIMICROBIAL BAN}

Aim for the withdrawal of antimicrobial agents used was to prevent humans and animals from drug resistance. The ban on antimicrobial growth promoters led to decreased drug resistance in some bacteria. For example, according to report from the DANMAP, substantial reductions (from 80 to $2 \%$ ) in the prevalence of vancomycin-resistant enterococci (VRE) were observed after ban of avoparcin as the growth promoter during 1995 and 2010 (DANMAP, 2010). E. faecium and Enterococcus faecalis are two of the most common Enterococci species and in Europe, only vancomycin-resistant E. faecium (VREF) is highly prevalent in poultry (Werner et al., 2008). VREF was still present as a threat in the food chain even after 15 years of the EU ban on avoparcin and could be detected in $47 \%$ of the broiler feces with a selective enrichment method (Garcia-Migura et al., 2007; DANMAP, 2010).

The ban on tylosin as the growth promoter had a remarkable effect on the level of macrolide (erythromycin) resistance in Campylobacter coli (most common Campylobacter species in pigs) from pigs as it decreased from 66 to $20 \%$ in Denmark between 1998 and 2005 (Hammerum et al., 2007). However, DANMAP data showed that during 2006-2010, macrolide resistance in $C$. coli varied within the range of $10-20 \%$ without significant reduction (DANMAP, 2010). In contrast to EU, macrolides (e.g., tylosin) in USA had been approved for usage in food-producing animals as growth promoter for decades. Macrolide resistance in $C$. coli isolated from poultry, although higher than that in C. jejuni, has no significant change (5-20\%) between 2002 and 2010.

Use of enrofloxacin in poultry was withdrawn by US-FDA in 2005 because it was supposed to induce fluoroquinolone resistance in Campylobacter and Salmonella from poultry and contribute to the antibiotic treatment failure in humans [Food and Drug Administration (FDA), 1998, 2002; Nelson et al., 2007]. After withdrawal of enrofloxacin from poultry, the rate of fluoroquinolone resistance in Campylobacter and Salmonella had been reduced in chicken during 2005-2007 (NARMS, 2010). Human clinicians also observed a reduction in domestically acquired Campylobacter and Salmonella infections with decreased susceptibility to fluoroquinolones, and it was thought to be a great achievement regarding public health (Nelson et al., 2007). However, the incidence rate of fluoroquinolone-resistant C. jejuni, from chicken breast, again increased (15.2 22.5\%) in 2008-2010. Similarly, fluoroquinolone-resistant Campylobacter from broilers was also raised from 5.3 to $8.6 \%$ and from 0.8 to $7.7 \%$ in Denmark and Japan, respectively (CIPARS, 2008; JVARM, 2008; DANMAP, 2010; NARMS, 2010).

\section{CONCLUSION AND PERSPECTIVES}

Definite targeting of pathogens, well-known mechanisms of activity, and preferable stability for administration are the unique advantages of antimicrobial use in food-animals for the prevention and treatment of bacterial and parasitic diseases, improvement of animal production performance, and protection of environment and public health. Withdrawal of antimicrobial use from food-producing animals may bring adverse effects on the production of food derived from animals and thus, on public health. EU banned only low-dose antibiotics (5 40 ppm) for their use as growth promoters in food animals. Until now, without helping for the cause, it led to some negative effects on food animal production and public health. What will happen if the antimicrobial agents are banned worldwide, especially in some developing countries with rapid increase in human population and food demand?

As a double-edged sword, non-rational uses of veterinary antimicrobials may result in pressure selection of antimicrobial resistant pathogens which may endanger both the animal and public health. Additionally, the presence of antibiotic residues in the environment, associated with overuse of antimicrobial drugs, may adversely influence the manure treatment systems by inhibition of biogas production. An economic analysis about use and withdrawal of antimicrobial growth promoters in USA revealed that the withdrawal may cause increased cost ( $\$ 10 /$ person) for food consumption and antibiotic-resistant infections cost the US healthcare system an excess of $\$ 20$ billion (\$60/person) annually (APUA, 2010). However, it is unknown that how much of these $\$ 20$ billion is due to antimicrobial resistance associated with their use in food-producing animals.

Recently, the US FDA has also proposed restrictions on the antimicrobial growth promoters because some available information and evidences suggested that the sub-therapeutic use may increase the risk of antimicrobial resistance. To make wise 
strategies for controlling antimicrobial resistance and effectively respond to the public health concerns associated with drug resistance, FDA believes that it is very important and imperative to consider how antimicrobial drugs are being used and how to address their injudicious uses in nature. Only rational use and effective regulation can ensure a benefit-risk balance of the antimicrobial application in animal production. However, longterm policies will be required for the international regulation of antibiotic use in food-producing animals.

\section{ACKNOWLEDGMENTS}

This article is supported by National Natural Science Foundation of China (31101856), Grants from National Basic Research program of China (2013CB127200), National Key Technology R\&D Program (2012BAK01B00) and the research fund for young scholars in the Doctoral Program of Higher Education of China (2011014612003).

\section{REFERENCES}

Akkermans, J. P., and Vecht, U. (1994). Streptococcal infections as cause of death in pigs brought in for necropsy. Tijdschr. Diergeneeskd. 119, 123-128.

Alali, W. Q., Scott, H. M., Harvey, R. B., Norby, B., Lawhorn, D. B., and Pillai, S. D. (2008). Longitudinal study of antimicrobial resistance among Escherichia coli isolates from integrated multisite cohorts of humans and swine. Appl. Environ. Microbiol. 74, 3672-3681. doi: 10.1128/AEM.02624-07

Alexander, T. W., Inglis, G. D., Yanke, L. J., Topp, E., Read, R. R., Reuter, T., et al. (2010). Farm-to-fork characterization of Escherichia coli associated with feedlot cattle with a known history of antimicrobial use. Int. J. Food Microbiol. 137, 40-48. doi: 10.1016/j.ijfoodmicro.2009.11.008

Alexopoulos, C., Tsinas, A., Kantas, D., Florou-Paneri, P., Read, M. P., Vassilopoulos, V., et al. (1998). A dose titration study on the effect of virginiamycin on specific blood parameters and milk quality in the sow. Zentralbl. Veterinarmed. 45, 535542. doi: 10.1111/j.1439-0442.1998.tb00857.x

Allen, H. K., Levine, U. Y., Looft, T., Bandrick, M., and Casey, T. A. (2013). Treatment, promotion, commotion: antibiotic alternatives in food-producing animals. Trends Microbiol. 21, 114-119. doi: 10.1016/j.tim.2012.11.001

Altwegg, M., and Geiss, H. K. (1989). Aeromonas as a human pathogen. Crit. Rev. Microbiol. 16, 253-286. doi: 10.3109/10408418909105478

AMI. (2010). Antibiotic Use in Livestock Production: Ensuring Meat Safety, American Meat Institute. Available at: http://www.MeatAMI.com

Amin, M. M., Hashemi, H., Ebrahimi, A., and Ebrahimi, A. (2012). Effects of oxytetracycline, tylosin, and amoxicillin antibiotics on specific methanogenic activity of anaerobic biomass. Int. J. Environ. Health Eng. 1, 1-4. doi: 10.4103/2277-9183.102356

APUA. (2010). The Cost of Antibiotic Resistance to U.S Families and the Health Care System. A.f.t.P.U.o., ed. Available at: http://www.tufts.edu/med/apua/consumers/ personal_home_5_1451036133.pdf

Carraschi, S. P., da Cruz, C., Machado Neto, J. G., Ignácio, N. F., Barbuio, R., and Machado, M. R. (2012). Histopathological biomarkers in pacu (Piaractus mesopotamicus) infected with Aeromonas hydrophila and treated with antibiotics. Ecotoxicol. Environ. Saf. 83, 115-120. doi: 10.1016/j.ecoenv.2012.06.016

Casewell, M., Friis, C., Marco, E., McMullin, P., and Phillips, I. (2003). The European ban on growth-promoting antibiotics and emerging consequences for human and animal health. J. Antimicrob. Chemother. 52, 159-161. doi: 10.1093/jac/ $\mathrm{dkg} 313$

Center for Food Safety [CFS]. (2013). Animal Factories and Environmental Pollution. Available at: http://www.centerforfoodsafety.org/issues/307/ animal-factories/animal-factories-and-environmental-pollution\#

CIPARS. (2008). Canadian Integrated Program for Antimicrobial Resistance Surveillance Annual Report 2008. Available at: http://www.phac-aspc.gc.ca/ cipars-picra/2008/index-eng.php

Cook, R. (1999). EU ban on four antibiotic growth promoters. Vet. Rec. 144, 158.

Cox, L. A. Jr. (2005). Potential human health benefits of antibiotics used in food animals: a case study of virginiamycin. Environ. Int. 31, 549-563. doi: 10.1016/j.envint.2004.10.012
Cromwell, C. L. (2002). Why and how antibiotics are used in swine production. Anim. Biotechnol. 13, 7-27. doi: 10.1081/ABIO-120005767

Cromwell, G. L. (1999). "Subtherapeutic use of antibiotics for swine: performance, reproductive efficiency and safety issues," in Proceeding of 40th George A. Young Swine Health and Management Conference, Lincoln, 69-87.

Cromwell, G. L., and Stahly, T. S. (1985). Efficacy of tiamulin as a growth promotant for growing swine. J. Anim. Sci. 60, 14-19.

Cromwell, G. L., Stahly, T. S., Jensen, A. H., Plumlee, M. P., Krider, J. L., and Russett, J. C. (1984a). Efficacy of thiopeptin as a growth promotant for growing barrows and gilts - a cooperative study. J. Anim. Sci. 59, 892-895.

Cromwell, G. L., Stahly, T. S., Speer, V. C., and O'Kelly, R. (1984b). Efficacy of nosiheptide as a growth promotant for growing-finishing swine - a cooperative study. J. Anim. Sci. 59, 1125-1128.

Cunha, T. J., Meadows, G. B., Edwards, H. M., Sewell, R. F., Pearson, A. M., and Glasscock, R. S. (1951). A comparison of aureomycin, streptomycin, penicillin and an aureomycin-B12 feed supplement for the pig. Arch. Biochem. 30, 269-271.

DANMAP. (2010). DANMAP - Use of Antimicrobial Agents and Occurrence of Antimicrobial Resistance in Bacteria from Food Animals, Food and Humans in Denmark. Available at: http://www.danmap.org

Dibner, J. J., and Richards, J. D. (2005). Antibiotic growth promoters in agriculture: history and mode of action. Poult. Sci. 84, 634-643. doi: 10.1093/ps/84.4.634

Dodds, W. K., Priscu, J. C., and Ellis, B. K. (1991). Seasonal uptake and regeneration of inorganic nitrogen and phosphorus in a large oligotrophic lake: size-fractionation and antibiotic treatment. J. Plankton Res. 13, 1339-1358. doi: 10.1093/plankt/13.6.1339

Domescik, E. J., and Martin, S. A. (1999). Effects of laidlomycin propionate and monensin on the in vitro mixed ruminal microorganism fermentation. J. Anim. Sci. 77, 2305-2312.

Doyle, M. P., and Erickson, M. C. (2006). Reducing the carriage of foodborne pathogens in livestock and poultry. Poult. Sci. 85, 960-973. doi: 10.1093/ps/85.6.960

Drouin, E. (1999). Helicobacter pylori: novel therapies. Can. J. Gastroenterol. 13, 581-583.

Elder, R. O., Keen, J. E., Wittum, T. E., Callaway, T. R., Edrington, T. S., Anderson, R. C., et al. (2002). "Intervention to reduce fecal shedding of enterohemorrhagic Escherichia coli O157:H7 in naturally infected cattle using neomycin sulfate," in American Society of Animal Science/American Dairy Science Association Joint Meeting, Quebec, 602.

Emborg, H. D., Ersboll, A. K., Heuer, O. E., and Wegener, H. C. (2002). "Effects of termination of antimicrobial growth promoter use for broiler health and productivity," in International Invitational Symposium; Beyond Anti Microbial Growth Promoters in Food Animal Production, November 6-7 2002, Foulum, $38-42$.

EPC. (2005). Ban on Antibiotics as Growth Promoters in Animal Feed Enters into Effect, European Commission - IP/05/1687. Available at: http://europa.eu/rapid/press-release_IP-05-1687_en.htm

Falkow, S. (1970). Antibiotics in animal feeds. N. Engl. J. Med. 282, 693-694. doi: 10.1056/NEJM197003192821230

Food and Agriculture Organization (FAO). (2006). Livestock Impacts on the Environment, Food and Agriculture Organization of the United Nations, Agriculture and Consumer Protection Department. Available at: http://www.fao.org/ag/magazine/0612sp1.htm

Food and Agriculture Organization [FAO]. (2009). The State of Food and Agriculture: Livestock in the Balance. Available at: http://www.fao.org/docrep/012/i0680e/i0680 e00.htm

Food and Agriculture Organization [FAO]. (2012). The State of Food Insecurity in the World 2012. Available at: http://www.fao.org/docrep/016/i3027e/i3027e00.htm

Food and Drug Administration (FDA). (1998). Freedom of information summary NADA 1412068, htm, h.w.f.g.c.f., ed.

Food and Drug Administration (FDA). (2002). Final decision of the Commissioner Docket No. 2000 N21571 with drawal of approval of the new animal drug application for enrofloxacin in poultry [EB/OL]. Available at: [http://www.fda.gov/oc/antimicrobial/baytri.html]

Fellner, V., Sauer, F. D., and Kramer, J. K. (1997). Effect of nigericin, monensin, and tetronasin on biohydrogenation in continuous flow-through ruminal fermenters. J. Dairy Sci. 80, 921-928. doi: 10.3168/jds.S0022-0302(97)76015-6

Forman, C. R., and Burch, J. E. (1947). Use of sodium sulfonamides as single injection specific treatment in foot rot. J. Am. Vet. Med. Assoc. 111, 208-214. 
Franti, C. E., Adler, H. E., and Julian, L. M. (1971). Antibiotic growth promotion: effects of bacitracin and oxytetracycline on intestines and selected lymphoid tissues of New Hampshire cockerels. Poult. Sci. 50, 94-99. doi: 10.3382/ps.0500094

Franklyn, K. B. (2010). Poultry Culture, Sanitation and Hygiene (1915). Whitefish, MT: Kessinger Publishing.

Franti, C. E., Julian, L. M., Adler, H. E., and Wiggins, A. D. (1972). Antibiotic growth promotion: effects of zinc bacitracin and oxytetracycline on the digestive, circulatory, and excretory systems of New Hampshire cockerels. Poult. Sci. 51, 1137-1145. doi: 10.3382/ps.0511137

Gaggia, F., Mattarelli, P., and Biavati, B. (2010). Probiotics and prebiotics in animal feeding for safe food production. Int. J. Food Microbiol. 141(Suppl. 1), S15-S28. doi: 10.1016/j.ijfoodmicro.2010.02.031

Garcia-Migura, L., Liebana, E., Jensen, L. B., Barnes, S., and Pleydell, E. (2007). A longitudinal study to assess the persistence of vancomycin-resistan Enterococcus faecium (VREF) on an intensive broiler farm in the United Kingdom. FEMS Microbiol. Lett. 275, 319-325. doi: 10.1111/j.1574-6968.2007. 00911.x

GIA. (2012). Animal Health Market to Hit $\$ 43$ Billion in Five Years. Available at: http://westernfarmpress.com/management/animal-health-market-hit43-billion-five-years

GRACE. (2013). The Issue: Antibiotics and the Food Animal Industry. Available at: http://www.sustainabletable.org/257/antibiotics, GRACE Communications Foundation.

Guan, H., Wittenberg, K. M., Ominski, K. H., and Krause, D. O. (2006). Efficacy of ionophores in cattle diets for mitigation of enteric methane. J. Anim. Sci. 84, 1896-1906. doi: 10.2527/jas.2005-652

Haenni, M., Saras, E., Chatre, P., Medaille, C., Bes, M., Madec, J. Y., et al. (2012) A USA300 variant and other human-related methicillin-resistant Staphylococcus aureus strains infecting cats and dogs in France. J. Antimicrob. Chemother. 67, 326-329. doi: 10.1093/jac/dkr499

Halling-Sorensen, B., Sengelov, G., Ingerslev, F., and Jensen, L. B. (2003). Reduced antimicrobial potencies of oxytetracycline, tylosin, sulfadiazin, streptomycin, ciprofloxacin, and olaquindox due to environmental processes. Arch. Environ. Contam. Toxicol. 44, 7-16. doi: 10.1007/s00244-002-1234-Z

Hammerum, A. M., Heuer, O. E., Lester, C. H., Agerso, Y., Seyfarth, A. M., Emborg, H. D., et al. (2007). Comment on: withdrawal of growth-promoting antibiotics in Europe and its effects in relation to human health. Int. J. Antimicrob. Agents 30, 466-468. doi: 10.1016/j.ijantimicag.2007.07.012

Hardy, B. (1999). "A world without growth promoters," in First Annual Turtle Lake Science Conference (Nottingham: Nottingham University Press).

Harvey, R., Funk, J., Wittum, T. E., and Hoet, A. E. (2009). A metagenomic approach for determining prevalence of tetracycline resistance genes in the fecal flora of conventionally raised feedlot steers and feedlot steers raised without antimicrobials. Am. J. Vet. Res. 70, 198-202. doi: 10.2460/ajvr.70.2.198

He, S., Zhou, Z., Meng, K., Zhao, H., Yao, B., Ringo, E., et al. (2011). Effects of dietary antibiotic growth promoter and Saccharomyces cerevisiae fermentation product on production, intestinal bacterial community, and nonspecific immunity of hybrid tilapia (Oreochromis niloticus female $\times$ Oreochromis aureus male). J. Anim. Sci. 89, 84-92. doi: 10.2527/jas.2010-3032

Heikkila, A. M., Nousiainen, J. I., and Pyorala, S. (2012). Costs of clinical mastitis with special reference to premature culling. J. Dairy Sci. 95, 139-150. doi: 10.3168/jds.2011-4321

Hemaprasanth, K. P., Kar, B., Garnayak, S. K., Mohanty, J., Jena, J. K., and Sahoo, P. K. (2012). Efficacy of two avermectins, doramectin and ivermectin against Argulus siamensis infestation in Indian major carp, Labeo rohita. Vet. Parasitol. 190, 297-304. doi: 10.1016/j.vetpar.2012.05.010

Heuer, O. E., Pedersen, K., Andersen, J. S., and Madsen, M. (2001). Prevalence and antimicrobial susceptibility of thermophilic Campylobacter in organic and conventional broiler flocks. Lett. Appl. Microbiol. 33, 269-274. doi: 10.1046/j.1472-765X.2001.00994.x

Hewes, C. G. (1955). The influence on the growth and progeny of the guinea pig resulting from oral administration of aureomycin (chloretracycline) and penicillin. J. Nutr. 57, 353-360.

Hoflack, G., Maes, D., Mateusen, B., Verdonck, M., and de Kruif, A. (2001). Efficacy of tilmicosin phosphate (Pulmotil premix) in feed for the treatment of a clinical outbreak of Actinobacillus pleuropneumoniae infection in growing-finishing pigs. J. Vet. Med. 48, 655-664. doi: 10.1046/j.1439-0450.2001.00492.x
Hook, S. E., Wright, A. D., and McBride, B. W. (2010). Methanogens: methane producers of the rumen and mitigation strategies. Archaea 2010, 945785. doi: $10.1155 / 2010 / 945785$

Hosking, B. C., Griffiths, T. M., Woodgate, R. G., Besier, R. B., Le Feuvre, A. S., Nilon, P., et al. (2009). Clinical field study to evaluate the efficacy and safety of the amino-acetonitrile derivative, monepantel, compared with registered anthelmintics against gastrointestinal nematodes of sheep in Australia. Aust. Vet. J. 87, 455-462. doi: 10.1111/j.1751-0813.2009.00511.x

Hower, S., Phillips, M. C., Brodsky, M., Dameron, A., Tamargo, M. A., Salazar, N. C., et al. (2013). Clonally related methicillin-resistant Staphylococcus aureus isolated from short-finned pilot whales (Globicephala macrorhynchus), human volunteers, and a Bayfront Cetacean Rehabilitation Facility. Microb. Ecol. 65, 1024-1038. doi: 10.1007/s00248-013-0178-3

Hurd, H. S., Brudvig, J., Dickson, J., Mirceta, J., Polovinski, M., Matthews, N., et al. (2008). Swine health impact on carcass contamination and human foodborne risk. Public Health Rep. 123, 343-351.

Hurd, H. S., Gailey, J. K., McKean, J. D., and Griffith, R. W. (2005). Variable abattoir conditions affect Salmonella enterica prevalence and meat quality in swine and pork. Foodborne Pathog. Dis. 2, 77-81. doi: 10.1089/fpd. 2005.2.77

Hurd, H. S., Yaeger, M. J., Brudvig, J. M., Taylor, D. D., and Wang, B. (2012). Lesion severity at processing as a predictor of Salmonella contamination of swine carcasses. Am. J. Vet. Res. 73, 91-97. doi: 10.2460/ajvr.73.1.91

IFAH-EuroP. (2005). IFAH - Europe Annual Report 2005. Available at: httP://www.ifaheuroPe.org/Publieations/IFAH_EuroPe_AR_2005.Pdf

Jensen, G. B., Hansen, B. M., Eilenberg, J., and Mahillon, J. (2003). The hidden lifestyles of Bacillus cereus and relatives. Environ. Microbiol. 5, 631-640. doi: 10.1046/j.1462-2920.2003.00461.x

JETACAR. (1999). The Use of Antibiotics in Food Producing Animals. Report of the Joint Expert Advisory Committee on Antibiotic Resistance. Canberra: Commonwealth of Australia, Resistance, 107-116.

Jones, C. M. (2010). The Effects of Selected Antibiotics on Nitrogen Uptake by Spirodela Punctata. M.S. thesis, Humboldt State University, Arcata.

Jones, R. L. (2000). Clostridial enterocolitis. Vet. Clin. N. Am. 16, 471-485.

Jukes, T. H. (1970). Antibiotics in animal feeds. N. Engl. J. Med. 282, 49-50. doi: 10.1056/NEJM197001012820116

JVARM. (2008). A Report on the Japanese Veterinary Antimicrobial Resistance Monitoring System 2002-2007. Tokyo: National Veterinary Assay Laboratory, Ministry of Agriculture, Forestry and Fisheries.

Kantas, D., Vassilopoulos, V., Kyriakis, S. C., and Saoulidis, K. (1998). A dose titration study on the effect of virginiamycin on gilt/sow and piglet performance. Zentralb. Veterinarmed. 45, 525-533. doi: 10.1111/j.1439-0442.1998.tb0 0856.x

Knarreborg, A., Lauridsen, C., Engberg, R. M., and Jensen, S. K. (2004). Dietary antibiotic growth promoters enhance the bioavailability of alphatocopheryl acetate in broilers by altering lipid absorption. J. Nutr. 134, 1487-1492.

Kobayashi, Y. (2010). Abatement of methane production from ruminants: trends in the manipulation of rumen fermentation Asian-Aust. J. Anim. Sci. 23, 410-416.

Krausse, R., and Schubert, S. (2010). In-vitro activities of tetracyclines, macrolides, fluoroquinolones and clindamycin against Mycoplasma hominis and Ureaplasma spp. isolated in Germany over 20 years. Clin. Microbiol. Infect. 16, 1649-1655.

Krehbiel, C. (2013). The role of new technologies in global food security: Improving animal production efficiency and minimizing impacts. Anim. Front. 3, 4-7. doi: 10.2527/af.2013-0017

Lallai, A., Mura, G., and Onnis, N. (2002). The effects of certain antibiotics on biogas production in the anaerobic digestion of pig waste slurry. Bioresour. Technol. 82, 205-208. doi: 10.1016/S0960-8524(01)00162-6

Larsen, J., Anderson, N., and Preshaw, A. (2009). Long-acting moxidectin for the control of trichostrongylid infections of sheep in southeastern Australia. Aust. Vet. J. 87, 130-137. doi: 10.1111/j.1751-0813.2009. 00395.x

Lindemann, M. D., and Kornegay, E. T. (1989). Folic acid supplementation to diets of gestating-lactating swine over multiple parities. J. Anim. Sci. 67, 459-464.

Lindemann, M. D., Kornegay, E. T., Stahly, T. S., Cromwell, G. L., Easter, R. A., Kerr, B. J., et al. (1985). The efficacy of salinomycin as a growth promotant for swine from 9 to $97 \mathrm{~kg}$. J. Anim. Sci. 61, 782-788. 
Loftin, K. A., Henny, C., Adams, C. D., Surampali, R., and Mormile, M. R. (2005). Inhibition of microbial metabolism in anaerobic lagoons by selected sulfonamides, tetracyclines, lincomycin, and tylosin tartrate. Environ. Toxicol. Chem. 24, 782-788. doi: 10.1897/04-093R.1

Loncaric, I., Kubber-Heiss, A., Posautz, A., Stalder, G. L., Hoffmann, D., Rosengarten, R., et al. (2013). Characterization of methicillin-resistant Staphylococcus spp. carrying the mecC gene, isolated from wildlife. J. Antimicrob. Chemother. 68 , 2222-2225. doi: 10.1093/jac/dkt186

Lovland, A., and Kaldhusdal, M. (2001). Severely impaired production performance in broiler flocks with high incidence of Clostridium perfringens-associated hepatitis. Avian Pathol. 30, 73-81. doi: 10.1080/03079450020023230

Matthews, K. (2001). Antimicrobial drug use and veterinary costs in U.S. livestock production, Agriculture Information Bulletin No. (AIB-766), 761-768.

Manson, E. R. (1968). Antibiotics in animal feeds. Aust. Vet. J. 44, 169-173. doi: 10.1111/j.1751-0813.1968.tb09069.x

Marshall, B. M., and Levy, S. B. (2011). Food animals and antimicrobials: impacts on human health. Clin. Microbiol. Rev. 24, 718-733. doi: 10.1128/CMR.00 002-11

McKellar, Q. A., Midgley, D. M., Galbraith, E. A., Scott, E. W., and Bradley, A. (1992) Clinical and pharmacological properties of ivermectin in rabbits and guinea pigs. Vet. Rec. 130, 71-73. doi: 10.1136/vr.130.4.71

Mead, P. S., Slutsker, L., Dietz, V., McCaig, L. F., Bresee, J. S., Shapiro, C., et al. (1999a). Food-related illness and death in the United States. Emerg. Infect. Dis. 5, 607-625. doi: 10.3201/eid0505.990502

Mead, P. S., Slutsker, L., Griffin, P. M., and Tauxe, R. V. (1999b). Food-related illness and death in the United States reply to Dr. Hedberg. Emerg. Infect. Dis. 5, 841-842. doi: 10.3201/eid0506.990625

Mellata, M. (2013). Human and avian extraintestinal pathogenic Escherichia coli: infections, zoonotic risks, and antibiotic resistance trends. Foodborne Pathog. Dis. 10, 916-932. doi: 10.1089/fpd.2013.1533

Midtvedt, T. (1986). Effects of antimicrobial agents upon the functional part of the intestinal flora. Scand. J. Infect. Dis. 49, 85-88.

Moore, P. R., and Evenson, A. (1946). Use of sulfasuxidine, streptothricin, and streptomycin in nutritional studies with the chick. J. Biol. Chem. 165, 437-441.

Nagaraja, T. G., and Taylor, M. B. (1987). Susceptibility and resistance of ruminal bacteria to antimicrobial feed additives. Appl. Environ. Microbiol. 53, 1620 1625.

NARMS. (2010). Retail Meat Report - National Antimicrobial Resistance Monitoring System. Available at: http://www.fda.gov/AnimalVeterinary/SafetyHealth/ AntimicrobialResistance/NationalAntimicrobialResistanceMonitoringSystem/ default.htm

Nelson, J. M., Chiller, T. M., Powers, J. H., and Angulo, F. J. (2007). Fluoroquinoloneresistant Campylobacter species and the withdrawal of fluoroquinolones from use in poultry: a public health success story. Clin. Infect. Dis. 44, 977-980. doi: $10.1086 / 512369$

Niewold, T. A. (2007). The nonantibiotic anti-inflammatory effect of antimicrobial growth promoters, the real mode of action? A hypothesis. Poult. Sci. 86, 605-609. doi: $10.1093 / \mathrm{ps} / 86.4 .605$

Norin, K. E. (1997). Influence of antibiotics on some intestinal microflora associated characteristics. Anaerobe 3, 145-148. doi: 10.1006/anae.1997.0091

Nunes, K. (2008). Hogs raised without antibiotics carry more pathogens. Food Business News, 12th June.

Odongo, N. E., Bagg, R., Vessie, G., Dick, P., Or-Rashid, M. M., Hook, S. E., et al. (2007). Long-term effects of feeding monensin on methane production in lactating dairy cows. J. Dairy Sci. 90, 1781-1788. doi: 10.3168/jds. 2006-708

Partanen, K., Siljander-Rasi, H., Pentikainen, J., Pelkonen, S., and Fossi, M. (2007). Effects of weaning age and formic acid-based feed additives on pigs from weaning to slaughter. Arch. Anim. Nutr. 61, 336-356. doi: 10.1080/17450390 701556866

Phillips, G. (1999). Microbiological aspects of clinical waste. J. Hosp. Infect. 41, 1-6. doi: 10.1016/S0195-6701(99)90029-4

Phillips, I. (2007). Withdrawal of growth-promoting antibiotics in Europe and its effects in relation to human health. Int. J. Antimicrob. Agents 30, 101-107. doi: 10.1016/j.ijantimicag.2007.02.018

Phillips, I., Casewell, M., Cox, T., De Groot, B., Friis, C., Jones, R., et al. (2004a). Antibiotic use in animals. J. Antimicrob. Chemother. 53, 885. doi: 10.1093/jac/dkh149
Phillips, I., Casewell, M., Cox, T., De Groot, B., Friis, C., Jones, R., et al. (2004b). Does the use of antibiotics in food animals pose a risk to human health? A critical review of published data. J. Antimicrob. Chemother. 53, 28-52. doi: 10.1093/jac/dkg483

Poduval, R. D., Kamath, R. P., Corpuz, M., Norkus, E. P., and Pitchumoni, C. S. (2000). Clostridium difficile and vancomycin-resistant enterococcus: the new nosocomial alliance. Am. J. Gastroenterol. 95, 3513-3515. doi: 10.1111/j.15720241.2000.03291.x

Reports, Q. (2012). China Veterinary Drug Industry 2012 Market Research Report. Available at: http://www.qyresearchreports.com/report/china-veterinary-drug -industry-2012-market-research-report.htm

Rodehutscord, M., Abel, H. J., Friedt, W., Wenk, C., Flachowsky, G., Ahlgrimm, H. J., et al. (2002). Consequences of the ban of by-products from terrestrial animals in livestock feeding in Germany and the European Union: alternatives, nutrient and energy cycles, plant production, and economic aspects. Archiv fur Tierernahrung 56, 67-91. doi: 10.1080/00039420214180

Rose, N., Beaudeau, F., Drouin, P., Toux, J. Y., Rose, V., and Colin, P. (1999). Risk factors for Salmonella enterica subsp. enterica contamination in French broilerchicken flocks at the end of the rearing period. Prev. Vet. Med. 39, 265-277. doi: 10.1016/S0167-5877(99)00002-1

Rumpler, W. V., Johnson, D. E., and Bates, D. B. (1986). The effect of high dietary cation concentration on methanogenesis by steers fed diets with and without ionophores. J. Anim. Sci. 62, 1737-1741.

Russell, J. B., and Jeraci, J. L. (1984). Effect of carbon monoxide on fermentation of fiber, starch, and amino acids by mixed rumen microorganisms in vitro. Appl. Environ. Microbiol. 48, 211-217.

Russell, S. M. (2003). The effect of air sacculitis on bird weights, uniformity, fecal contamination, processing errors, and populations of Campylobacter spp. and Escherichia coli. Poult. Sci. 82, 1326-1331. doi: 10.1093/ps/82.8.1326

Sarmah, A. K., Meyer, M. T., and Boxall, A. B. (2006). A global perspective on the use, sales, exposure pathways, occurrence, fate and effects of veterinary antibiotics (VAs) in the environment. Chemosphere 65, 725-759. doi: 10.1016/j.chemosphere.2006.03.026

Scarfe, A. D., Lee, C.-S., and O’Bryen, P. J. (2011). Aquaculture Biosecurity: Prevention, Control, and Eradication of Aquatic Animal Disease. Oxford: Blackwell Publishers.

Schelling, G. T. (1984). Monensin mode of action in the rumen. J. Anim. Sci. 58, 1518-1527.

Shi, J. C., Liao, X. D., Wu, Y. B., and Liang, J. B. (2011). Effect of antibiotics on methane arising from anaerobic digestion of pig manure. Anim. Feed Sci. Technol. 166-167, 457-463. doi: 10.1016/j.anifeedsci.2011.04.033

Soma, J. A., and Speer, V. C. (1975). Effects of pregnant mare serum and chlortetracycline on the reproductive efficiency of sows. J. Anim. Sci. 41, 100-105.

Sun, J. P., Zheng, P., and Hu, B. L. (2009). [Combined effect of antibiotics on anaerobic digestion of piggery wastewater]. Huan jing ke xue $=$ Huanjing kexue / [bian ji, Zhongguo ke xue yuan huan jing ke xue wei yuan hui. Huan jing ke xue $30,2619-2624$.

Taylor, J. H., and Gordon, W. S. (1955). Growth-promoting activity for pigs of inactivated penicillin. Nature 176, 312-313. doi: 10.1038/176312a0

Tice, A. (2001). Outpatient parenteral antimicrobial therapy (OPAT): a global perspective. Introduction. Chemotherapy 47(Suppl. 1), 1-4. doi: 10.1159/0000 48562

Turnidge, J. (2004). Antibiotic use in animals - prejudices, perceptions and realities. J. Antimicrob. Chemother. 53, 26-27. doi: 10.1093/jac/dkg493

USFDA. (2009). Summary Report on Antimicrobials Sold or Distributed for Use in Food-Producing Animals. Department of Health and Human Services. Available at: http://www.fda.gov/downloads/ForIndustry/UserFees/AnimalDrugUserFeeAct ADUFA/UCM231851.pdf

Van Lunen, T. A. (2003). Growth performance of pigs fed diets with and without tylosin phosphate supplementation and reared in a biosecure all-in all-out housing system. Can. Vet. J. 44, 571-576.

Van Nevel, C., and Demeyer, D. I. (1995). Lipolysis and biohydrogenation of soybean oil in the rumen in vitro: inhibition by antimicrobials. J. Dairy Sci. 78, 2797-2806. doi: 10.3168/jds.S0022-0302(95)76910-7

Van Nevel, C. J., and Demeyer, D. I. (1977). Effect of monensin on rumen metabolism in vitro. Appl. Environ. Microbiol. 34, 251-257.

Varga, C., Rajic, A., McFall, M. E., Reid-Smith, R. J., Deckert, A. E., Checkley, S. L., et al. (2009). Associations between reported on-farm antimicrobial use 
practices and observed antimicrobial resistance in generic fecal Escherichia coli isolated from Alberta finishing swine farms. Prev. Vet. Med. 88, 185-192. doi: 10.1016/j.prevetmed.2008.10.002

Verkade, E., and Kluytmans, J. (2013). Livestock-associated Staphylococcus aureus CC398: animal reservoirs and human infections. Infect. Genet. Evol. 21, 523-530. doi: 10.1016/j.meegid.2013.02.013

Vieira, A. R., Collignon, P., Aarestrup, F. M., McEwen, S. A., Hendriksen, R. S., Hald, T., et al. (2011). Association between antimicrobial resistance in Escherichia coli isolates from food animals and blood stream isolates from humans in Europe: an ecological study. Foodborne Pathog. Dis. 8, 1295-1301. doi: 10.1089/fpd.2011.0950

Vogel, G., Nicolet, J., Martig, J., Tschudi, P., and Meylan, M. (2001). Pneumonia in calves: characterization of the bacterial spectrum and the resistance patterns to antimicrobial drugs. Schweiz. Arch. Tierheilkd. 143, 341-350.

Wahlstrom, R. C., Terrill, S. W., and Johnson, B. C. (1950). Effect of antibacterial agents on growth of baby pigs fed a "synthetic" diet. Proc. Soc. Exp. Biol. Med. 75, 710-711. doi: 10.3181/00379727-7518314

Weber, T. E., Schinckel, A. P., Houseknecht, K. L., and Richert, B. T. (2001). Evaluation of conjugated linoleic acid and dietary antibiotics as growth promotants in weanling pigs. J. Anim. Sci. 79, 2542-2549.

Werner, G., Coque, T. M., Hammerum, A. M., Hope, R., Hryniewicz, W., Johnson, A., et al. (2008). Emergence and spread of vancomycin resistance among enterococci in Europe. Euro Surveill. 13, pii: 19046.

Wierup, M. (2001). The Swedish experience of the 1986 year ban of antimicrobial growth promoters, with special reference to animal health, disease prevention, productivity, and usage of antimicrobials. Microb. Drug Resist. 7, 183-190. doi: $10.1089 / 10766290152045066$
Yano, Y., Yokoyama, M., Satomi, M., Oikawa, H., and Chen, S. S. (2004). Occurrence of Vibrio vulnificus in fish and shellfish available from markets in China. J. Food Prot. 67, 1617-1623.

Zhang, J. J., Wang, L. X., Ruan, W. K., and An, J. (2013). Investigation into the prevalence of coccidiosis and maduramycin drug resistance in chickens in China. Vet. Parasitol. 191, 29-34. doi: 10.1016/j.vetpar.2012. 07.027

Zhou, Z., He, S., Liu, Y., Cao, Y., Meng, K., Yao, B., et al. (2011). Gut microbial status induced by antibiotic growth promoter alters the prebiotic effects of dietary DVAQUA(R) on Aeromonas hydrophila-infected tilapia: production, intestinal bacterial community and non-specific immunity. Vet. Microbiol. 149, 399-405. doi: 10.1016/j.vetmic.2010.11.022

Conflict of Interest Statement: The authors declare that the research was conducted in the absence of any commercial or financial relationships that could be construed as a potential conflict of interest.

Received: 22 February 2014; accepted: 24 May 2014; published online: 12 June 2014. Citation: Hao H, Cheng G, Iqbal Z, Ai X, Hussain HI, Huang L, Dai M, Wang Y, Liu Z and Yuan $Z$ (2014) Benefits and risks of antimicrobial use in food-producing animals. Front. Microbiol. 5:288. doi: 10.3389/fmicb.2014.00288

This article was submitted to Antimicrobials, Resistance and Chemotherapy, a section of the journal Frontiers in Microbiology.

Copyright (C) 2014 Hao, Cheng, Iqbal, Ai, Hussain, Huang, Dai, Wang, Liu and Yuan. This is an open-access article distributed under the terms of the Creative Commons Attribution License (CC BY). The use, distribution or reproduction in other forums is permitted, provided the original author(s) or licensor are credited and that the original publication in this journal is cited, in accordance with accepted academic practice. No use, distribution or reproduction is permitted which does not comply with these terms. 